\section{CRYSTALLOGRAPHIC STUDIES OF 3D-COMPLEXES WITH CYANAMIDONITRATE}

J. Garcia Diaz ${ }^{1}$ J. Kozisek ${ }^{2}$ V. Langer ${ }^{3}$

${ }^{1}$ Institute Technological Of Morelia Materials Department Av. Morelos Norte 1500 Col. Lomas De Santiaguito MORELIA MICHOACAN 58120 MEXICO ${ }^{2}$ Department of Physical Chemistry, Slovak University of Technology, SK-812 37, Bratislava, Slovakia ${ }^{3}$ Department of Environmental Inorganic Chemistry, Chalmers University of Technology, SE-41296Goteborg, Sweden

The cyanamido-nitrate ligand has potentially four donor atoms: $\mathrm{N}$ (amide), $\mathrm{N}$ (nitrile) and two $\mathrm{O}$ atoms. The variety of coordination opportunities for cyanamidonitrate ligand (monodentate, or bidentate bridging ligand), in dependence on the kind of the central atom, especially on its hardness is expected. New cyanamidonitrate complex of composition $\left[\mathrm{Cu}\left(\mathrm{NO}_{2} \mathrm{NCN}\right)_{2}(\mathrm{dmpz})_{3}\right]($ where $(\mathrm{dmpz})=3,5$-dimethylpyrazole $)$ was prepared and the crystal structure solved. The crystal structure is built from discrete $\left[\mathrm{Cu}\left(\mathrm{NO}_{2} \mathrm{NCN}\right)_{2}(\mathrm{dmpz})_{3}\right]$ units. The central $\mathrm{Cu}$ (II) atom is found to be in the tetragonal-pyramid coordination. In equatorial plane there are three 3,5dimethylpyrazole molecules and one cyanamidonitrate anion coordinated by nitrile nitrogen atom. The axial position is completed by nitrile nitrogen atom from another cyanamidonitrate anion. Interatomic distances are compared and discussed with others solved crystal structures: $\left[\mathrm{Cu}\left(\mathrm{NO}_{2} \mathrm{NCN}\right)_{2}(1 \text {-meiz })_{4}\right]$ [1], $\left[\mathrm{Cu}\left(\mathrm{NO}_{2} \mathrm{NCN}\right)_{2}(5 \text {-meiz })_{4}\right]$ [1], [Cu( $\left.\left.\mathrm{NO}_{2} \mathrm{NCN}\right)_{2}(\mathrm{iz})_{2}\right]$ [2], [ $\mathrm{Ni}\left(\mathrm{NO}_{2} \mathrm{NCN}\right)_{2}(1-$ meiz) $\left.)_{4}\right]$ [3], $\left[\mathrm{Ni}\left(\mathrm{NO}_{2} \mathrm{NCN}\right)_{2}(\mathrm{pz})_{4}\right][4]$ and $\left[\mathrm{Co}\left(\mathrm{NO}_{2} \mathrm{NCN}\right)_{2}(\mathrm{iz})_{4}\right]$ [3] (where meiz $=$ methylimidazole, $\mathrm{iz}=$ imidazole, $\mathrm{pz}=$ pyrazole $)$.

Acknowledgment Authors would like to thank to COSNET by the partly support of this work.

References

[1] Kohout J., Hvastijova M., Kozisek J., Diaz, J.G., Valko M., Jager L. and Svoboda I., Inorg. Chimica Acta, 287, 186 (1999)

[2] Kozisek J., Diaz, J.G., Hvastijova M. and Jager L., Acta Cryst., C53, 703 (1997)

[3] Hvastijova M., Kohout J., Kozisek J., Jager L. and Diaz, J.G., Polyhedron, 19, 1021 (2000)

[4] Hvastijova M., Kohout J., Diaz, J.G., Kozisek J. and Buchler J.W., Transit. Metal Chem., 26, 4/5, 430 (2001)

Keywords: NON LINEAR PSEUDOHALIDE, CYANAMIDONITRATE, 3-5 DIMETHLPYRAZOLE

Acta Cryst. (2002). A58 (Supplement), C131

\section{BIS(2-METHYLQUINOLINE N-OXIDE)ZINC CHLORIDE(II) AND} BIS(QUINOLINE N-OXIDE)COPPER(II) CHLORIDE

${ }_{\text {S.N. Ivashevskaja }}{ }^{1}$ L.A. Aleshina ${ }^{1}$ V.V. Chernyshev ${ }^{2}$

${ }^{1}$ Petrozavodsk State University Department of Solid State Physics Pr. Lenina 33 PETROZAVODSK KARELIA 185640 RUSSIA ${ }^{2}$ Chemistry Department, Moscow State University, 119899 Moscow, Russia

Heteroaromatic n-oxides are unique compounds due to n-o group which can serve either as electronoacceptor or as electronodonor, that depends on compound structure [1]. Their complexes and salts have broad spectrum of biological activities: some of them are used as medical remedies and plant growth activators.

$\mathrm{X}$-ray powder diffraction patterns were obtained on two high-resolution powder diffractometers: Guinier de Wolff camera and X'pert diffractometer (Cu-Kalpha1 radiation). Unit cell dimensions were determined with the program TREOR [2]. The structures of the title compounds were determined by the MRIA program [3] using grid search [4] and simulated annealing [5] techniques. The subsequent bond-restrained Rietveld refinement gave bond lengths and angles within the expected ranges.

Crystal data of $\mathrm{Bis}(2$-methylquinoline $\mathrm{N}$-oxide) zinc chloride(II): The unit cell is orthorhombic, Pbcn; a = 14.048(6), b = 10.192(5), c = 14.051(6) $\AA ; \mathrm{Z}=4$; $\mathrm{Mr}=$ 454.46. Bragg $\mathrm{R}$-factor $\mathrm{Rb}=10.7$, profile factor $\mathrm{Rp}=7.1$. Crystal data of Bis(quinoline N-oxide)copper(II) chloride: The unit cell is monoclinic, $P 2_{1} / n$; a $=11.780(3), \mathrm{b}=14.872(5), \mathrm{c}=6.061(2) \AA, \beta=98.27(2)^{\circ}$.; $\mathrm{Z}=4 ; \mathrm{Mr}=279.51$. Bragg $\mathrm{R}$-factor $\mathrm{Rb}=7.9$, profile factor $\mathrm{Rp}=5.4$. Space group was assumed during the structure determination. Profile function: split-type pseudo-Voigt. Preferred orientation correction: symmetrized harmonics expansion [6]. References

1. A. Albini, S. Pietra Heterocyclic N-oxides, 1991.

2. Werner, P.-E., Eriksson, L., Westdahl, M. (1985). J. Appl. Cryst. 18, 367370 .

3. Zlokazov, V.B. and Chernyshev, V.V. (1992). J. Appl. Cryst. 25, 447-451.

4. Chernyshev, V.V. and Schenk, H. (1998). Z. Kristallogr. 213, 1-3.

5. Zhukov, S.G., Chernyshev, V.V., Babaev, E.V., Sonneveld, E.J., Schenk H.(2001). Z. Kristallogr. 216, 5-9.

6. Jarvinen, M. (1993). J. Appl. Cryst. 26, 525-531.

Keywords: CRYSTAL STRUCTURE, X-RAY POWDER DIFFRACTION, MOLECULAR COMPLEX
Acta Cryst. (2002). A58 (Supplement), C131

CRYSTAL STRUCTURE OF $\mathrm{Na}_{2}\left[\left\{\mathrm{Cu}_{2}\left(\mathrm{O}_{2} \mathrm{CH}\right)_{4}\right\}\left\{\mathrm{Cu}\left(\mathrm{O}_{2} \mathrm{CH}\right)_{4}\right\}\right]$ A. Golobic M. Malekovic P. Segedin

Faculty of Chemistry and Chemical Technology, University of Ljubljana, Askerceva 5 LJUBLJANA SI-1001 SLOVENIA

The title compound represents the first case of copper coordination compound with alternating dimeric tetracarboxylato and monomeric formate units. Crystal Data: $\mathrm{C}_{4} \mathrm{H}_{4} \mathrm{Cu}_{1.5} \mathrm{NaO}_{8}, \mathrm{Mr}=298.38$, triclinic, $P-1$, No. $2, \mathrm{Z}=2$, a $=$ 7.6594(2), $\mathrm{b}=7.7717(1), \mathrm{c}=8.7972(2) \AA, \alpha=113.248(1), \beta=108.653(1), \chi=$ $97.495(1)^{\circ}, \mathrm{V}=435.61(1) \AA^{3}, \mathrm{Dx}=2.275 \mathrm{Mgm}^{-3}, \lambda(\mathrm{MoK} \alpha)=0.71073 \mathrm{~A}$, Nonius Kappa CCD diffractometer, $\mathrm{T}=293(1) \mathrm{K}$, Rint $=0.038, \mathrm{R}=0.056$ We acknowledge the financial support through grant MŠZŠ PS-511-103.

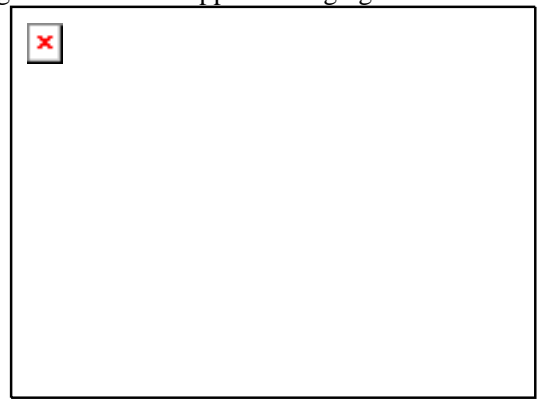

Keywords: CRYSTAL STRUCTURE COORDINATION COMPOUND COPPER FORMATE

\section{Acta Cryst. (2002). A58 (Supplement), C131}

\section{CRYSTAL AND MOLECULAR STRUCTURE OF TRIS(3,5- DIMETHYL-1-THIOCARBOXAMIDEPYRAZOLATO)Co(III), $\mathrm{Co}(\mathrm{L}-\mathrm{H})_{3}$}

Z.K. Jacimovic ${ }^{1}$ G. Giester ${ }^{2}$ Z.D. Tomic ${ }^{3}$ V.M. Leovac

${ }^{1}$ Faculty of Metallurgy And Techology General And Inorganic Chemistry Cetinjski Put Bb. PODGORICA MONTENEGRO, YUGOSLAVIA 81000 YUGOSLAVIA ${ }^{2}$ Institut für Mineralogie und Kristallographie, Universität Wien, Wien, Austria, ${ }^{3}$ 'Vinca' Institute of Nuclear Sciences, Belgrade, Yugoslavia, ${ }^{4}$ University of Novi Sad, Faculty of Sciences, Institute of Chemistry, Novi Sad, Yugoslavia

We have carried out investigations of the family of the pyrazole based ligands, and their transition metal complexes, with aim to determine influence of different substituents on the coordination geometry. In the course of this work we have synthesized new ligand 3,5-dimethyl -1- thiocarboxamidepyrazole (L) and the cobalt(III) complex $\mathrm{Co}(\mathrm{L}-\mathrm{H})_{3}$ have been structurally characterized. Crystal data: $\mathrm{Co}_{18} \mathrm{H}_{24} \mathrm{~N}_{9} \mathrm{~S}_{3}, P 2_{1} / c, \lambda(\mathrm{Mo} \mathrm{K} \alpha)=0.71073 \AA$, a $=8.750(2) \AA, \mathrm{b}$ $=18.390(4) \AA, c=30.485(6) \AA, \beta=91.49(3)^{\circ}, Z=8$, Data / restr. $/$ par. $=9487$ $/ 0 / 559, \mathrm{~S}=1.075, \mathrm{R}$ (all data) $=0.0825$, $\mathrm{wR} 2=0.1718$, Asymmetric unit contains two molecules of complex which did not show significant differences in the geometrical parameters. Ligands are coordinated in the fac fashion through the three 'pyridine' nitrogen placed in the equatorial plane, while the remaining positions are occupied by the amino nitrogens.The coordination geometry can be described as deformed octahedral. In the coordination polyhedron the shortest bonds are formed between the Co and two axial amino nitrogens $(1.895 / 1.892 \AA)$ while the longest bond are between the Co and pyridine nitrogen trans to amino nitrogen $(1.950 / 1.945 \AA$ A $)$. Angle formed by the trans pyridine nitrogens is $168.2 / 168.8^{\circ}$, with the dihedral angle between the pyrazole mean planes of $78^{\circ}$. Molecules are mutually connected by the system of the $\mathrm{N}(\mathrm{amino})-\mathrm{H}$...S hydrogen bonds, ( 2.50-2.86 $\left.\AA, 163-170^{\circ}\right)$ forming a rows connected by the van der Walls interactions.

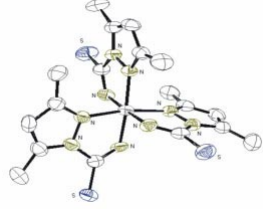

Keywords: 3,5-DIMETHYL-1-THIOCARBOXAMIDEPYRAZOLE, CO(III) COMPLEX, STRUCTURE 